\title{
Effect of claw disorders on milk production, fertility, and longevity, and their economic impact in Spanish Holstein cows
}

\author{
N. Charfeddine* and M. A. Pérez-Cabalt ${ }^{1}$ \\ *Spanish Holstein Association (CONAFE), 28340 Valdemoro, Spain \\ †Department of Animal Production, Complutense University of Madrid, 28040 Madrid, Spain
}

\begin{abstract}
The aims of this study were (1) to estimate the phenotypic association between different degrees of severity of claw disorders and production, fertility performance, and longevity in Spanish dairy cattle, and (2) to quantify its economic impact at the animal and herd level. In this study, claw data comprised 108,468 trimmings collected between 2012 and 2014 by 25 trimmers from 804 Holstein dairy herds. The claw disorders considered were the 3 most frequent disorders in Spanish dairy herds: dermatitis (DE), sole ulcer (SU), and white line disease (WL). The presence of SU or WL was associated with a significant decrease in milk production and was more important in cows in second or later lactations. A severe lesion of SU or WL lead to twice the milk losses associated with a mild lesion, ranging from 1.47 to $2.66 \mathrm{~kg} / \mathrm{d}$ of energy-corrected milk. The presence of SU or WL during the early lactation period was associated with more days open, fewer inseminations to get pregnant, and longer calving to first service interval (4.83 and $8.0 \mathrm{~d}$ longer due to mild and severe lesions of SU, respectively, and 4.94 and $17.43 \mathrm{~d}$ longer due to mild and severe lesions of WL, respectively). The occurrence of a case of SU or WL in first lactation had a significant effect on longevity, with severe lesions reducing up to $71 \mathrm{~d}$ of productive life. The cost of a mild lesion ranged from $\$ 53$ to $\$ 232$ per affected cow and year, whereas the cost of a severe lesion ranged from $\$ 402$ to $\$ 622$ per affected cow and year. The annual costs per cow for DE, SU, and WL were $\$ 10.80$, $\$ 50.9$, and $\$ 43.2$, respectively. An average herd with 64 cows had an extra expenditure of $\$ 691 / \mathrm{yr}$ due to DE, $\$ 3,256 /$ yr due to SU, and $\$ 2,765 /$ year due to WL. Milk losses, longer calving intervals, and premature culling contributed to more than half of the costs. Therefore, providing this information to farmers could help decide
\end{abstract}

Received May 10, 2016.

Accepted October 14, 2016.

${ }^{1}$ Corresponding author: mapcabal@vet.ucm.es on strategies to reduce the incidence of claw disorders on the farm.

Key words: claw disorder, cost, loss, performance

\section{INTRODUCTION}

Lameness is one of the major production diseases in intensive dairy production farming. Intensive selection for high milk production has led to an increase in milk yield in the past few decades but has also increased the incidence of claw disorders and resulted in declining longevity in modern dairy cows (Oltenacu and Algers, 2005). Simultaneously, in response to the demand for high productivity, modern and intensive husbandry with freestall open barns was implemented, which has led to a higher risk of claw disorders (Bell et al., 2009). One-third of the cows present in Spanish Holstein dairy herds have been shown to experience at least one claw disorder per year (Charfeddine and Pérez-Cabal, 2014a). In other countries, such as the United Kingdom, estimates of prevalence ranged from 21\% (Clarkson et al., 1996) to 36\% (Leach et al., 2010); in the Netherlands, more than $70 \%$ of Dutch cows have at least one claw disorder (Somers et al., 2003; van der Waaij et al., 2005).

Claw disorders are responsible for $92 \%$ of lameness (Murray et al., 1996), and lameness has been associated with a decreased productivity (Amory et al., 2008), reduced fertility rates (Hernandez et al., 2001), and an increased risk of premature culling (Booth et al., 2004). Different types of claw disorders can be classified as infectious (e.g., interdigital dermatitis and digital dermatitis) and noninfectious (e.g., sole ulcer and white line disease), and each claw disorder has a specific effect on cow performance. Many authors have reported that cows affected by claw disorders have reduced milk production compared with unaffected cows for several weeks, or even months, before and after diagnosis (e.g., Warnick et al., 2001; Green et al., 2002, 2010). Huxley (2013) summarized that a lame cow may produce between 270 and $574 \mathrm{~kg}$ less milk per lactation and highlighted the difficulty in comparing the wide range 
of values given in the literature, due to the different ways of describing lameness and the methodologies used for analysis. Rajala-Schultz et al. (1999) estimated the milk loss to be 1.5 to $2.8 \mathrm{~kg} / \mathrm{d}$, which means that the total loss per lactation was $310.5 \mathrm{~kg}$. Amory et al. (2008) analyzed the association of specific lesions and milk production on 30 dairy cow farms in England and Wales. They estimated milk loss attributed to SU and WL of 1.5 and $0.8 \mathrm{~kg} / \mathrm{d}$, respectively, resulting in total losses over lactation of 574 and $369 \mathrm{~kg}$, respectively. However, for digital dermatitis, the differences between affected and unaffected cows were not significant. Hernandez et al. (2002) found that interdigital phlegmon was associated with a $10 \%$ decrease in 305 -d matureequivalent milk yield. Claw disorders also have adverse effects on fertility in dairy cows (e.g., Hultgren et al., 2004). A lame cow has longer calving-to-first-service and calving-to-conception intervals (Collick et al., 1989; Barkema et al., 1994; Hernandez et al., 2001) and needs more inseminations to get pregnant (Collick et al., 1989; Buch et al., 2011). Melendez et al. (2003) reported that cows with claw problems showed lower first-service conception rate (17.5 vs. $42.6 \%$ in control cows) and higher incidence of ovarian cysts. Consequently, animals with claw health problems are more likely to be culled (Booth et al., 2004). Onyiro et al. (2008) reported a negative correlation between EBV for digital dermatitis and longevity (as length of productive life). However, the magnitude of the effect of claw disorders on longevity is not as widely reported as effects on production and fertility, perhaps because only severe cases are susceptible to immediate culling, when the mobility of the cow is seriously compromised.

Knowing the degree of severity of lameness is also essential to define performance losses. In the literature, different degrees of lameness led to different effects on production and fertility, albeit not always significant (Hernandez, 2005; Olechnowicz and Jaśkowski, 2015), probably because these studies were carried out on a limited number of cows. However, Bicalho et al. (2007), with around 2,000 cows, found that the interval from calving to conception and the hazard ratio of culling increased as the severity of lameness increased.

The economic impact of claw disorders has been reported in several papers (Kossaibati and Esslemont, 1997; Booth et al., 2004; Cha et al., 2010), where the estimation of losses was done both at the cow level and at the herd level. The costs due to claw disorders were estimated using different methodologies, such as partial budgeting (Willshire and Bell, 2009) and dynamic optimization programming (Cha et al., 2010). Claw health costs are often split into direct and indirect costs. Direct costs are easy to quantify and include treatment, the veterinarian or trimmer visit and time charge, the cost of extra farmer time, and the cost of discarded milk. Indirect costs include mainly the reduction of milk yield, the premature culling, and the extension of the calving interval. Willshire and Bell (2009) estimated overall costs of $\$ 100.5, \$ 689.91$, and $\$ 399.06$ per case in the United Kingdom for digital dermatitis, sole ulcer, and white line disease, respectively. Few studies, however, have assessed the economic impact of each disorder differentiating between mild and severe lesion. The degree of severity depends mainly on when the farmer detects the lesion of the affected cow and when it is treated. Therefore, the incidence rate, the degree of severity, the relapse rates, and the duration of each claw disorder may determine the total economic loss. The farmer must then be aware of the cost of each disorder and the consequences of detecting a mild or a severe lesion. This would demonstrate the benefits of implementing good practices, such as detecting lesions and applying treatments earlier and, consequently, improving claw health in the herd. For this purpose, it is important to have a good estimate of the indirect costs associated with losses in milk production, fertility, and longevity, and of the direct costs of each claw disorder and for each degree of severity.

Hence, the aims of the present study were (1) to estimate the impact of claw disorders on milk production, longevity, and reproductive performance, and (2) to quantify the costs of claw disorders in Spanish Holstein cows.

\section{MATERIALS AND METHODS}

\section{Claw Health Data}

Claw trimming information was obtained from the full claw health database of the I-SAP program (Information of claw health for lameness control and prevention; Charfeddine and Pérez-Cabal, 2014a). The data used in this study included 108,468 records corresponding to more than 48,895 lactations collected between 2012 and 2014 in 804 Holstein dairy herds by 25 trimmers. The I-SAP program was implemented by the Spanish Holstein Association (CONAFE, Valdemoro, Spain) in 2012 and collects data (the program is ongoing) for 6 claw disorders: interdigital and digital dermatitis (DE), sole ulcer (SU), white line disease (WL), interdigital hyperplasia, interdigital phlegmon, and chronic laminitis. The collection of health data is an easy procedure. Briefly, CONAFE provides each trimmer involved in the I-SAP program with a touchscreen PC tablet with DATPAT software (developed by CONAFE) for recordkeeping on farms. The trimmers scheduled their visits so that they visited every farm once or twice a year to trim all cows but they could 
also score in an emergency visit. In general, some cows need more claw trimming than others, and each farmer decides which cows have to be trimmed. On average, more than $80 \%$ of the cows in each herd are trimmed at least once a year; only cows observed by the trimmer are included in the claw health database. The trimmer connects via the Internet to download historical herd information from the database. The trimmer works on every scheduled cow for that visit, records the lesion, and scores the severity for each claw. Then, the trimmer sends information back to the database after each working day. The foot trimmer charges the farmer for the trimming service but recordkeeping is free of charge. Hoof trimmers are trained periodically with the aim of unifying criteria. We assumed that if a cow had 2 trimming records for the same claw within 28 d, it was the same lesion that needed to be treated again. A recurrent or relapse case occurred in the same claw if it was diagnosed again for the same condition $28 \mathrm{~d}$ after the last treatment. A detailed description of the procedure and claw disorders recorded within I-SAP is given by Pérez-Cabal and Charfeddine (2015). Each disorder was scored as a categorical trait for each claw, such that 1 = absence of disorder, $2=$ mild lesion, and $3=$ severe lesion. The difference between mild and severe lesions depended on each claw disorder. Mainly, the trimmer considered how deep or superficial the lesion was, the expected recovery time, and whether any further treatment was required. A mild lesion was superficial and did not affect the deeper tissue. A severe lesion invaded the deeper tissues of the horn, resulting in sepsis. For DE, a mild lesion was equivalent to stage M1 and a severe lesion was equivalent to stage M2 in the M-stage scoring system defined by Döpfer et al. (1997). Because of the low incidence of interdigital hyperplasia, interdigital phlegmon, and chronic laminitis in the population (see Pérez-Cabal and Charfeddine, 2015), this study was performed only for DE, SU, and WL.

\section{Milk Production Data}

Official milk recording data were merged with claw health data, and test-day milking records from 48,895 lactations provided by CONAFE were used to perform the phenotypic association analyses between milk production and claw disorders. Initially, the data set included 684,530 test-day milking records but after combining them with the claw trimming data, only 98,055 test-day milking records were used in the analyses. The editing of the data set was as follows.

Only records of one lactation per cow were considered. In the analysis of association of claw disorders with milk production, daily ECM was used as the outcome variable. Daily milk yield as well as fat and protein contents were used to calculate ECM according to the International Farm Comparison Network definition (IFCN, 2010), which determines the amount of milk produced adjusted to a standard $4 \%$ fat and $3.3 \%$ protein:

$$
\begin{gathered}
\mathrm{ECM}=[(0.383 \times \text { milk } \times \% \text { fat })+(0.242 \times \text { milk } \\
\times \% \text { protein })+(0.7832 \times \text { milk })] / 3.1138 .
\end{gathered}
$$

To avoid the confounding effect of different claw disorders present jointly, only records of healthy cows (i.e., without any claw disorder diagnosed) and records of cows with only one specific claw disorder at a time were included in the analyses of each disorder. The number of cows in each analysis was smaller than in the original database and this could have consequences on the significance of the effects but it is the best way to detect the individual effect of each disorder.

We were interested in estimating the effect of each claw disorder on ECM depending on when the disorder was diagnosed in relation to the test-day milking record date. Therefore, we used a classified effect for each specific claw disorder, called time, as an explanatory variable obtained as follows. First, we studied the intervals to define the classes and the relevant period around each test-day record in which the occurrence of the claw disorder had a statistically significant effect on production. We tested 7-d and 14-d intervals of diagnosis date for claw disorders up to 3 mo before and after the test-day date. With the shorter interval, we had estimation problems because of too few data for each level in the analysis and, therefore, we decided to use 14-d intervals. With our data, the preliminary analyses led to a relevant period of $\pm 28 \mathrm{~d}$ and a complete interval within $42 \mathrm{~d}$ before and $42 \mathrm{~d}$ after the test-day date to assign the time class. Therefore, if there was a trimming record within that period of \pm 42 $\mathrm{d}$, we coded the effect time in 5 classes: $1=$ test-day recorded between 15 and $28 \mathrm{~d}$ before the diagnosis, 2 = test-day recorded within $14 \mathrm{~d}$ before diagnosis, $3=$ test-day recorded within $14 \mathrm{~d}$ after diagnosis, $4=$ testday recorded between 15 and $28 \mathrm{~d}$ after diagnosis, and 5 $=$ cows that had not been diagnosed with any claw disorder within the $28 \mathrm{~d}$ before and $28 \mathrm{~d}$ after the test-day, either diagnosed as "healthy" (unaffected) during the trimming visit or with a claw disorder diagnosed within the intervals between 29 and $42 \mathrm{~d}$ before and after the test-day date. Class 5 was used as the reference level. Figure 1 represents how the explanatory variable time was coded. The same trimming record could affect up to 3 test-day records but was coded as different classes depending on the interval with respect to the test-day date. 


\section{Fertility Data}

Calving dates and dates of inseminations were retrieved from the official milk recording system and merged with claw data. According to the literature, claw disorders that appear in early stages of lactation have the largest effect on cow reproduction. Therefore, the effect of the presence of each of the claw disorders within the first $100 \mathrm{~d}$ of lactation was estimated on 3 fertility traits. We considered the early lactation period because our hypothesis was that the stress and pain of claw lesions affect ovarian activity, which may silence or delay detection of heat. The fertility traits considered as response variables in the analyses were days from calving to first service (CFS) and number of services per conception (SPC), both obtained from the reproductive records, and days open (DO), calculated as the difference between the calving interval obtained from the milking records and the pregnancy period of 282 d. To avoid confounding effects, only cows with a single specific claw disorder or without any lesion within $100 \mathrm{~d}$ of lactation were used in the analyses. A total of 15,159 lactations from 804 herds were finally used for analysis with fertility data.

\section{Longevity}

Longevity, defined as length of productive life (LPL), was measured as days between the first calving and the last milk recording. We used dates of last milk recording instead of culling dates because the dates of culling in the milk recording system were not fully reliable. The cow was considered as culled (complete record) if the number of days between the last day of milk recording for that cow and the last day of milk recording in the herd exceeded $180 \mathrm{~d}$. Otherwise, the record was considered censored. Only cows that had the opportunity to survive at least 72 mo were used as censored data.

The initial database with longevity information consisted of 50,813 registered cows, where $25 \%$ of them had censored data. Then, longevity information was merged with claw health data. Cows used in the analyses were required to have claw health information during the first lactation, and only the first trimming record was used for each cow. The final data set for the study of association with longevity consisted of 10,339 cows. The statistical description of traits used after editing is shown in Table 1.

\section{Association Analyses}

The phenotypic associations were evaluated by performing analyses of variance using PROC MIXED (SAS Institute Inc., Cary, NC). Initially, the predictor variables and their interactions were screened using a univariate approach, where variables with $P<0.20$ were retained in the general full model. The means comparison was assessed by applying the Dunnett test and using as reference the cows without any claw disor-

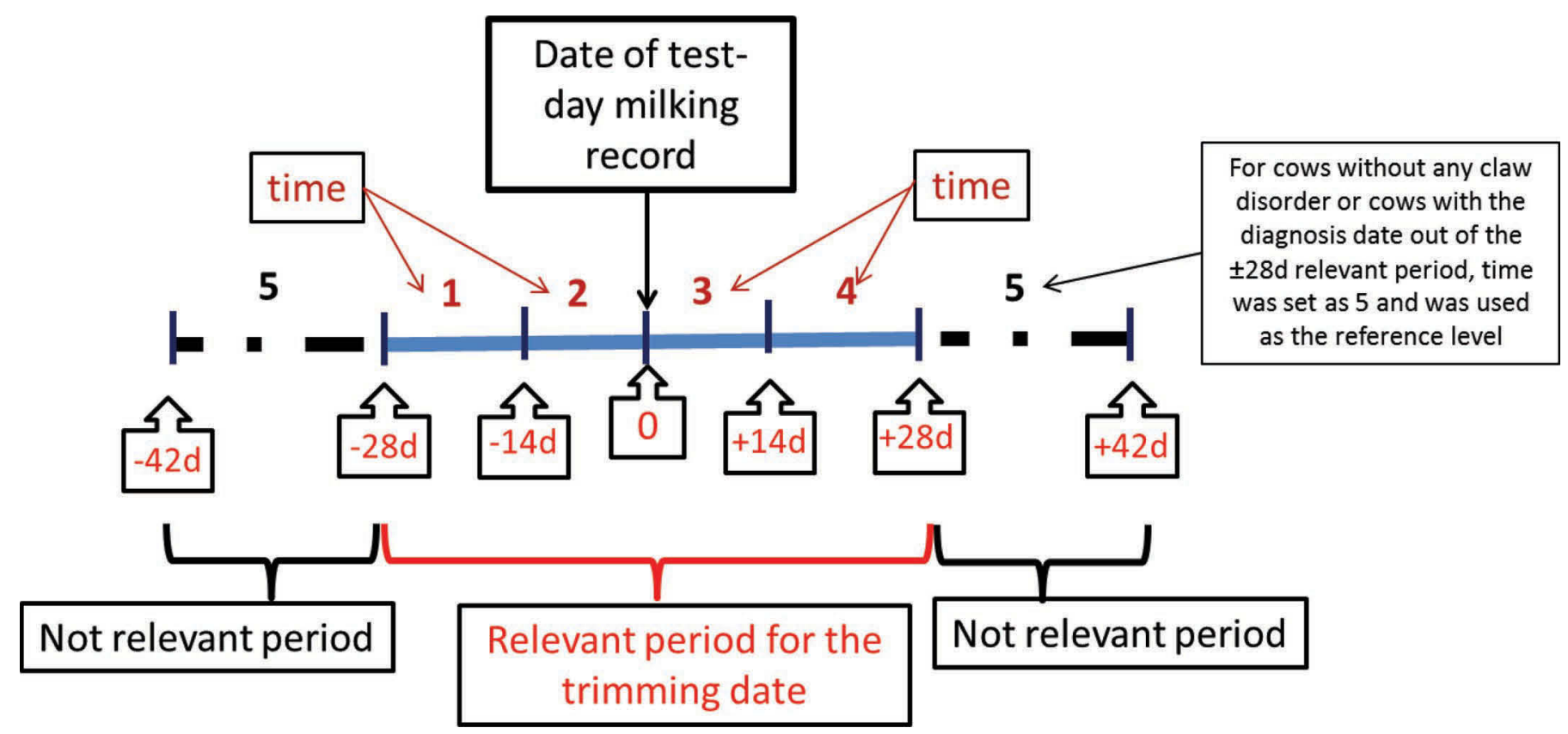

Figure 1. How the effect of time was coded for inclusion in the association analyses of claw disorders with milk production. Color version available online. 
ders during the period of study for production, fertility, and longevity.

\section{Effect of Claw Disorders on Production, Fertility, and Longevity}

In the case of ECM, the magnitude of the losses depends on the number of lactation (first lactation or later) and the severity of the claw disorder. Therefore, the analyses were performed including the interactions among the number of lactation, degree of severity, and time that were statistically significant in the previous tests.

The model fitted for ECM was

$$
\begin{aligned}
& \mathrm{y}_{\mathrm{ijklmnst}}=\mu+\operatorname{herd}_{\mathrm{i}}+\text { seas }_{\mathrm{j}}+\text { lact }_{\mathrm{k}} \times \text { age }_{\mathrm{l}}+\text { lact }_{\mathrm{k}} \\
& \times \text { stage }_{\mathrm{m}}+\operatorname{lact}_{\mathrm{k}} \times \operatorname{sev}_{\mathrm{n}} \times \text { time }_{\mathrm{s}}+\text { cow }_{\mathrm{t}}+\varepsilon_{\mathrm{ijklmnst}},
\end{aligned}
$$

where $\mu$ is the overall mean; herd $_{i}$ is the random effect of herd (804 levels); seas ${ }_{j}$ is the systematic effect of season of calving (4 levels: winter, spring, summer, fall); lact $_{k}$ is the systematic effect of number of lactations (2 levels: first lactation, second or later lactation); $a g e_{l}$ is the systematic effect of age at calving (48 levels); stage ${ }_{m}$ is the systematic effect of stage of lactation (11 levels: 10 thirty-day intervals plus level 11, which included DIM >300); $\operatorname{sev}_{n}$ is the systematic effect of degree of severity of the disorder (3 levels: absence of disorder, mild lesion, severe lesion); time $_{s}$ is the systematic effect of time (5 levels); cow $w_{t}$ is the random effect of cow (46,268 levels), which takes into account the correlation between repeated measures of the same individual; and $\varepsilon_{i j k l m n s t}$ is the random residual term. The joint distribution of random effects was

$$
\left(\begin{array}{c}
\text { herd } \\
\text { cow } \\
\boldsymbol{\varepsilon}
\end{array}\right) \sim N\left(\mathbf{0},\left(\begin{array}{ccc}
\mathbf{I} \sigma_{\text {herd }}^{2} & 0 & 0 \\
0 & \mathbf{I} \sigma_{\text {cow }}^{2} & 0 \\
0 & 0 & \mathbf{I} \sigma_{\varepsilon}^{2}
\end{array}\right)\right) \text {, }
$$

where $\mathbf{I}$ is an identity matrix, and $\sigma_{\text {herd }}^{2}, \sigma_{\text {cow }}^{2}$, and $\sigma_{\varepsilon}^{2}$ are the corresponding variances.

The model fitted for fertility traits (CFS, DO, and SPC) was

$$
\begin{aligned}
y_{i j k l m n}=\mu & + \text { herd }_{i}+\text { seas }_{j}+\text { lact }_{k} \times \text { prod_level }_{l} \\
& +C D_{100 m}+\operatorname{cow}_{n}+\varepsilon_{i j k l m n},
\end{aligned}
$$

where $\mu$ is the overall mean; herd ${ }_{i}$ is the random effect of herd (1,995 levels); seas ${ }_{j}$ is the systematic effect of season of calving (4 levels: winter, spring, summer, fall); lact $t_{k}$ is the systematic effect of number of lactations (2 levels: first lactation, second or later lactation); prod_level $l_{l}$ is the systematic effect of milk production level of the cow at $305 \mathrm{~d}$ (2 levels: low $<10,000 \mathrm{~kg}$ and high $\geq 10,000 \mathrm{~kg}) ; C D_{100 \mathrm{~m}}$ is the systematic effect of the diagnosis of each claw disorder within the first $100 \mathrm{~d}$ of lactation (3 levels: no diagnosis, mild lesion, severe lesion); $\operatorname{cow}_{n}$ is the random effect of cow $(15,159$ levels), which takes into account the correlation between repeated measures of the same individual, and $\varepsilon_{i j k l m n}$ is the random residual term. The joint distribution of random effects was

$$
\left(\begin{array}{c}
\text { herd } \\
\text { cow } \\
\varepsilon
\end{array}\right) \sim N\left(\mathbf{0},\left(\begin{array}{ccc}
\mathbf{I} \sigma_{\text {herd }}^{2} & 0 & 0 \\
0 & \mathbf{I} \sigma_{\text {cow }}^{2} & 0 \\
0 & 0 & \mathbf{I} \sigma_{\varepsilon}^{2}
\end{array}\right)\right)
$$

where $\mathbf{I}$ is an identity matrix, and $\sigma_{\text {herd }}^{2}, \sigma_{\text {cow }}^{2}$, and $\sigma_{\varepsilon}^{2}$ are the corresponding variances.

The model fitted for LPL was

$$
\begin{gathered}
y_{i j k l m n o p s}=\mu+\text { herd }_{i}+A F C_{j}+M F C_{k} \times n \text { trim }_{l} \\
+M D_{m}+F D_{n}+P D_{o}+C D_{p}+\text { cows }+\varepsilon_{i j k l m n o p s}
\end{gathered}
$$

where $\mu$ is the overall mean; herd $d_{i}$ is the random effect of herd (833 levels); $A F C_{j}$ is the systematic effect of age

Table 1. Mean, standard deviation, minima, and maxima of productive traits, fertility performance, and longevity

\begin{tabular}{lcccc}
\hline Trait $^{1}$ & Mean & SD & Minimum & Maximum \\
\hline Test-day milk (kg) & 33.8 & 9.7 & 4 & 84 \\
Test-day fat (\%) & 3.86 & 0.90 & 0.13 & 9.20 \\
Test-day protein (\%) & 3.29 & 0.37 & 0.10 & 5.97 \\
Test-day ECM (kg) & 32.82 & 9.31 & 2.61 & 104 \\
CFS (d) & 80.5 & 28.6 & 18 & 180 \\
DO (d) & 128.22 & 38.21 & 18 & 8 \\
SPC (no.) & 1.82 & 0.99 & 1 & 1,372 \\
LPL (d) & 532.19 & 251.45 & 65 & 8 \\
\hline
\end{tabular}

${ }^{1} \mathrm{CFS}=$ interval from calving to first service; $\mathrm{DO}=$ days open; $\mathrm{SPC}=$ number of services per conception; LPL $=$ length of productive life. 
Table 2. Annual incidence (\%) and relapse rates by number of lactation and degree of severity for each claw disorder

\begin{tabular}{|c|c|c|c|c|c|c|c|c|c|c|}
\hline \multirow[b]{3}{*}{ Disorder $^{1}$} & \multicolumn{5}{|c|}{ First lactation } & \multicolumn{5}{|c|}{ Second or later lactation } \\
\hline & \multirow[b]{2}{*}{ Total incidence } & \multicolumn{2}{|c|}{ Mild lesion } & \multicolumn{2}{|c|}{ Severe lesion } & \multirow{2}{*}{$\begin{array}{c}\text { Total } \\
\text { incidence }\end{array}$} & \multicolumn{2}{|c|}{ Mild lesion } & \multicolumn{2}{|c|}{ Severe lesion } \\
\hline & & Incidence & $\mathrm{RR}^{2}$ & Incidence & $\mathrm{RR}$ & & Incidence & $\mathrm{RR}$ & Incidence & $\mathrm{RR}$ \\
\hline $\mathrm{DE}$ & 16.6 & 15.6 & 1.97 & 1.0 & 2.02 & 13.9 & 13.1 & 2.24 & 0.8 & 2.60 \\
\hline $\mathrm{SU}$ & 9.5 & 8.2 & 2.38 & 1.3 & 3.13 & 21.4 & 18.6 & 2.46 & 2.8 & 3.14 \\
\hline WL & 8.8 & 7.4 & 2.50 & 1.4 & 2.89 & 18.7 & 16.1 & 2.65 & 2.6 & 2.98 \\
\hline
\end{tabular}

${ }^{1} \mathrm{DE}=$ dermatitis; $\mathrm{SU}=$ sole ulcer; $\mathrm{WL}=$ white line disease.

${ }^{2} \mathrm{RR}=$ relapse rate (total number of episodes of each disorder per year over the number of cows with that specific disorder).

at first calving (21 levels, from 20 to $40 \mathrm{mo}$ ); $M F C_{k}$ is the systematic effect of calendar month of first calving

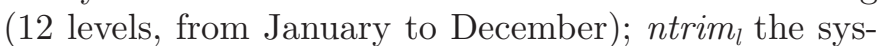
tematic effect of number of trimming visits within the first lactation (4 levels: $1,2,3$, and 4 or more trimming visits); $M D_{m}, F D_{n}$, and $P D_{o}$ are milk, fat, and protein yield percentage deviations regarding the average herdyear production levels considered as covariates; $C D_{p}$ is the systematic effect of the diagnosis of each claw disorder within the first lactation (3 levels: no diagnosis, mild lesion, severe lesion); cow $_{s}$ is the random effect of cow $(10,339$ levels $)$, and $\varepsilon_{i j k l m n o p s}$ is the random residual term. The joint distribution of random effects was

$$
\left(\begin{array}{c}
\text { herd } \\
\text { cow } \\
\varepsilon
\end{array}\right) \sim N\left(\mathbf{0},\left(\begin{array}{ccc}
\mathbf{I} \sigma_{\text {herd }}^{2} & 0 & 0 \\
0 & \mathbf{I} \sigma_{\text {cow }}^{2} & 0 \\
0 & 0 & \mathbf{I} \sigma_{\varepsilon}^{2}
\end{array}\right)\right),
$$

where $\mathbf{I}$ is an identity matrix, and $\sigma_{\text {herd }}^{2}, \sigma_{\text {cow }}^{2}$, and $\sigma_{\varepsilon}^{2}$ are the corresponding variances.

\section{Calculation of Claw Health Costs}

A deterministic model was used to calculate the costs of DE, SU, and WL using the incidence rates and relapse rates of each kind of lesion using data of 804 farms involved in the I-SAP program (Table 2). The information from an average Spanish Holstein herd, such as the number of cows, percentage of cows in first lactation, milk production, fat and protein contents, calving interval, milk price, and feed costs reported by Charfeddine and Pérez-Cabal (2014b) for the calculation of Spanish economic net merit index were used as inputs for the economic model (Table 3). Average daily milk production was $30.2 \mathrm{~kg} / \mathrm{cow}$ in first lactation. For second and later lactations, the average milk production was estimated as $117 \%$ of the production at first lactation. The marginal cost of premature culling was an opportunity cost calculated as the expected profit per day not produced as result of the culling. The expected profit was estimated from the lifetime profit function developed by Charfeddine and Pérez-Cabal (2014b), which took into account milk yield, calves, and salvage value as incomes, and feeding, rearing, and breeding costs as expenses. Using the same profit function, the marginal cost of an extra day open was estimated as the opportunity cost of a one-day-longer nonpregnancy period and the failure to start a new lactation.

Total costs were obtained as the sum of direct and indirect costs. Direct costs were obtained from a survey carried out among the trimmers involved in the I-SAP

Table 3. Information of an average herd used to estimate the costs of claw disorders (Charfeddine and PérezCabal, 2014b)

\begin{tabular}{lcc}
\hline Item & Average & SD \\
\hline Number of cows & 64 & 43 \\
Cows at first lactation (\%) & 29.1 & 2.01 \\
Milk production at first lactation $(\mathrm{kg} / \mathrm{cow}$ per day) & 30.2 & 1.96 \\
Fat content $(\%)$ & 3.8 & 0.90 \\
Protein content (\%) & 3.3 & 0.37 \\
Calving interval (d) & 424 & 68 \\
Milk price $(\$ / \mathrm{kg})$ & 0.38 & 0.02 \\
Feed price $(\$ / \mathrm{kg})$ & 0.21 & 0.01 \\
Marginal cost of an extra day open (\$/d) & 2.19 & 0.63 \\
Marginal cost of premature culling $(\$ / \mathrm{d})$ & 3.58 & 1.03 \\
Marginal input of ECM $(\$ / \mathrm{d})$ & 0.28 & 0.02 \\
\hline
\end{tabular}

${ }^{1}$ Adjusted to milk price in 2015 . 
program (Table 4$)$. Direct costs $\left(C_{\text {direct }}\right)$ were calculated as follows:

$$
C_{\text {direct }}=\sum_{i=1}^{\text {parity severity }} \sum_{j=1}\left(c_{t m}+c_{t r}+c_{d m}+c_{l a b}\right) \cdot I R_{i j} \cdot R R_{i j}
$$

where parity has 2 levels (first lactation and later); severity has 2 levels (mild and severe); $c_{t m}$ is treatment costs; $c_{d m}$ is discarded milk; $c_{t r}$ is trimmer costs, and $c_{l a b}$ is additional labor carried by the farmer; $I R_{i j}$ is the incidence rate of a claw disorder; and $R R_{i j}$ is the relapse rate, calculated as the total number of episodes of each disorder per year over the number of cows with that specific disorder. Treatment costs include medication, bandages, and hoof blocks. The cost of trimmer service included a visit fee and treatment time required for each disorder. The extra labor costs included the farmer's time to take care of the cows and to milk lame cows separately. The treatment and trimmer costs per case were calculated using treatment protocols for mild and severe lesions of each claw disorder. Severe lesions are usually treated with antibiotics on Spanish dairy farms, which results in $7 \mathrm{~d}$ of nonsaleable milk. In general, this milk is used to feed young stock, thus the cost of discarded milk was calculated based on the difference between the value of nonsaleable milk and powder milk.

Indirect costs $\left(C_{\text {indirect }}\right)$ were obtained as follows:

$$
C_{\text {indirect }}=\sum_{i=1}^{\text {parity severity }} \sum_{j=1}\left(c_{m y}+c_{d o}+c_{c u l}\right) \cdot I R_{i j} \cdot R R_{i j},
$$

where $c_{m y}$ are costs due to the reduction in milk production; $c_{d o}$ are costs due to longer DO interval; $c_{c u l}$ are costs due to a premature culling; $I R_{i j}$ is the incidence rate of a claw disorder; and $R R_{i j}$ is the relapse rate for each kind of lesion.

Production loss was calculated taking into account the estimated ECM production decrease, the duration of each disorder event, and the marginal ECM value. The marginal ECM value was calculated by considering the marginal milk price, fat and protein bonus, and marginal feed cost. Fertility deterioration loss due to each disorder was calculated based on additional days open and the marginal cost per day. The losses due to premature culling were based on a reduction of the productive life estimated for each disorder and the marginal profit loss due to the reduction of one day of productive life.

\section{RESULTS AND DISCUSSION}

\section{Frequencies of Claw Disorders}

Incidence rates and relapse rates associated with each disorder, with each degree of severity, depending on the lactation number, are shown in Table 2 . Incidence rates were calculated taking into consideration that all cows present in the herd were cows at risk. Dermatitis was the most frequent disorder in first lactation, whereas SU was most prevalent in cows of second or later lactations (Table 2). At least one disorder was present in almost $40 \%$ of the cows. The relapse rates per year ranged from 1.97 to 3.14 depending on the claw disorder, the degree of severity, and the lactation number. Taking all lactations into consideration, claw horn disruptions (SU and WL) were the most common and recurrent disorders in Spanish dairy herds. In North America, the infectious disorders (dermatitis and heel horn erosion) are by far the most common claw disorders (Cook, 2003; Cramer et al., 2008). The incidence rates of claw disorders observed in our data were within the range reported in the literature (van der Waaij et al., 2005; Uggla et al., 2008; Stoop et al., 2010) for Holstein cows from different populations. However, it must be noted that incidence rate can vary depending on multiple factors, mainly related to herd management, climate conditions, and recording system. The frequencies of severe lesions were very low compared with that of mild lesions, as reported by Pérez-Cabal and Charfeddine (2015), but we decided to distinguish both classes in this study because severe cases were associated with more relapses and later (delayed) detection.

Table 4. Costs used for the calculation of direct costs of each claw disorder ${ }^{1}$ according to their degree of

\begin{tabular}{|c|c|c|c|c|c|c|}
\hline \multirow[b]{2}{*}{ Cost } & \multicolumn{2}{|c|}{$\mathrm{DE}$} & \multicolumn{2}{|c|}{$\mathrm{SU}$} & \multicolumn{2}{|c|}{ WL } \\
\hline & Mild & Severe & Mild & Severe & Mild & Severe \\
\hline Trimmer visit (\$/event) & 10.41 & 13.88 & 10.41 & 17.34 & 10.41 & 17.34 \\
\hline Treatment (\$/event) & 1.73 & 6.94 & 13.88 & 23.13 & 13.88 & 23.13 \\
\hline Farmer extra labor $(\$$ /event) & 1.73 & 20.81 & 13.88 & 20.81 & 13.88 & 20.81 \\
\hline Discarded milk $(\$ / \mathrm{kg})$ & - & 0.17 & - & 0.17 & - & 0.17 \\
\hline
\end{tabular}
severity (mild and severe)

${ }^{1} \mathrm{DE}=$ dermatitis; $\mathrm{SU}=$ sole ulcer; $\mathrm{WL}=$ white line disease. 


\section{Effect of Claw Disorders on Milk Production}

Table 5 summarizes the effects of DE, SU, and WL on ECM for cows in first lactation and second or later lactations, depending on when the test-day was recorded in relation to the trimming date and the severity of the diagnosis. For cows in first lactation, there was only a statistically significant reduction in milk production due to SU compared with uninfected cows. Depending on the severity of the diagnosis, milk yield losses occurred within the 28- to 15-d interval before the test-day date for mild SU (10.08 kg lost during that period) and between the first day and $14 \mathrm{~d}$ after the test-day date for severe $\mathrm{SU}(25.20 \mathrm{~kg})$. However, as expected, all claw disorders studied had a significant effect on production for animals in second or later lactations. Dermatitis had a small or no effect on milk production of cows in first lactation, except for severe cases, although estimates were not statistically significant. For cows in second or later lactation, DE reduced milk production by $0.65 \mathrm{~kg} / \mathrm{d}$, on average, when the lesion was mild. However, for severe lesions, the effect was higher although the estimates were statistically not significant, probably due to the low frequency of severe cases of DE in our data. These results are consistent with those reported by Relun et al. (2013), even though they found a significant effect in cows in second or later lactation regardless of the degree of severity of the DE lesion. The noninfectious disorders SU and WL caused milk losses from $28 \mathrm{~d}$ before to $28 \mathrm{~d}$ after the test-day record, regardless of severity. Lischer and Ossent (2000) found that SU and WL can start some months before they are visible and diagnosed and that milk production is reduced even before diagnosis. In our study, the accumulated losses over 2 mo for a cow with mild or severe SU were 64.82 and $120.26 \mathrm{~kg}$, respectively, whereas a mild or severe WL produced losses of 39.62 and $121.24 \mathrm{~kg}$, respectively, compared with unaffected cows (only the statistically significant losses were considered). Compared with SU and WL, the milk loss caused by DE was low and occurred 1 mo before and $14 \mathrm{~d}$ after the test-day recording date (30.66 $\mathrm{kg}$ for a mild case). This is probably due to the metabolic background of SU and WL and a consequence of the energy balance the cow suffers during lactation. The digital cushion protects the corium and helps in weight bearing. During early lactation, cows mobilize adipose tissue, which also affects the digital cushion. The fatty acid composition and the thickness of the fat pad change (Räber et al., 2006) and limit the capacity to absorb pressure exerted by the third phalanx on the soft tissue beneath. Bicalho et al. (2009) found that cows in the upper quartile for digital cushion thickness had $15 \%$ lower prevalence of lameness than those in the lower quartile. The risk for horn lesions, such as SU and WL, is much higher in cows with chronic laminitis without the shock-absorbing fat pads, and the recovery period could be longer, which could lead to higher milk yield losses. Thus, changes in BCS, positively associated with changes in the digital cushion thickness, increase the risk of becoming lame (Green et al., 2014; Lim et al., 2015).

It is difficult to compare our results with other studies mainly because of the period of time around the diagnosis and the test-day dates, and the different response used, either lameness or claw disorders. Rajala-Schultz et al. (1999), using lameness as a general trait if a cow had one or more foot and leg disorders, reported that milk production in Finnish Ayrshire cows in first lactation started to decline 2 wk before diagnosis $(1.5 \mathrm{~kg} / \mathrm{d})$ of the disorder and continued to decrease until the end of lactation. For cows between the second and fourth lactation in that study, losses were higher (from 2.0 to $2.8 \mathrm{~kg} / \mathrm{d}$ ) but started at different times. Amory et al. (2008) suggested that the reduction in milk production can be an indicator of a claw disorder that has not yet been diagnosed, and losses after the trimming date are generally smaller than those before diagnosis, perhaps due to the success of the treatment applied. Warnick et al. (2001) studied the effect of the severity of lameness (measured as lesion on the foot, overgrowth of the hoof wall or treatment applied, depending on the herd) on milk yield in 2 herds of US Holstein cows but they only explored what happened after the diagnosis date. They found $\sim 3$-times-greater milk yield losses with severe lesions than with mild lesions but results between the 2 herds were inconsistent. In our study, only a 28-d interval around the test-day date was relevant; however, other authors found a relevant period of 5 mo before and after diagnosis (e.g., Green et al., 2002; Amory et al., 2008). Those studies reported milk losses of $360 \mathrm{~kg}$ due to lameness on a 305-d lactation basis in the United Kingdom, and they pointed out that losses before the diagnosis date could be confounded with occurrence of some disease other than a claw disorder.

\section{Effect of Claw Disorders on Fertility Performance}

The effect of claw disorders within the first $100 \mathrm{~d}$ of lactation on CFS, DO, and SPC are shown in Table 6. Except for CFS with mild DE lesions, we found no significant associations between DE and the fertility traits measured. There were relevant significant negative effects of SU and WL on reproductive performance. The major deterioration of reproductive performance was associated with WL. The increase in CFS interval due to a severe SU lesion was twice that of a mild event, 
compared with a cow with no disorder within the first $100 \mathrm{~d}$ of lactation. If the disorder was WL, the CFS interval was 4 times longer for a severe lesion than for a mild lesion. Cows that were diagnosed with SU or WL during early lactation also tended to have longer DO intervals, which was especially important when the disorder was severe (ranging from 8.59 to $17.37 \mathrm{~d}$ ), but they were likely to become pregnant with few SPC. These results were consistent with those obtained by Collick et al. (1989) and Fourichon et al. (2000). In both previous studies, the authors concluded that claw disorders were associated with an average increase of 14 and $12 \mathrm{~d}$, respectively, in the calving to conception interval, with wide variation depending on lesions and stage of occurrence. However, other studies (Bicalho et al., 2007; Olechnowicz and Jaśkowski, 2015) observed longer calving to conception intervals, ranging from 20 to $40 \mathrm{~d}$. Regarding the number of services per conception, cows with SU or WL lesions needed fewer services per conception than nonlame cows (Table 6), whereas
DE was not associated with number of services to get pregnant. Olechnowicz and Jaśkowski (2015) found results similar to ours. Garbarino et al. (2004) reported that claw disorders have a detrimental effect on ovarian activity during the early lactation period, delaying estrus cyclicity and, therefore, resulting in a longer anestrus period. Claw disorders cause pain and stress, increasing plasma levels of cortisol and delaying the onset of the surge of luteinizing hormone. The reduction in endogenous hormone as GnRH deprives the ovarian follicle of adequate gonadotropin support, which interferes with normal follicle growth (Dobson and Smith, 2000). This interference in ovarian activity may lead to a delay in estrus expression and complicates its detection, which may explain the low number of inseminations in cows affected by claw disorders. In addition, lame cows show a more negative energy balance than healthy cows, and it has been proven that weight loss inhibits ovarian follicular growth and development (De Vries and Veerkamp, 2000).

Table 5. Estimated effect of claw disorders ${ }^{1}$ on first and second or later lactation ECM production compared with a cow without any claw disorder (unaffected cow) and their corresponding SE, depending on the time interval between the trimming date and the test-day date, and the severity of the diagnosis

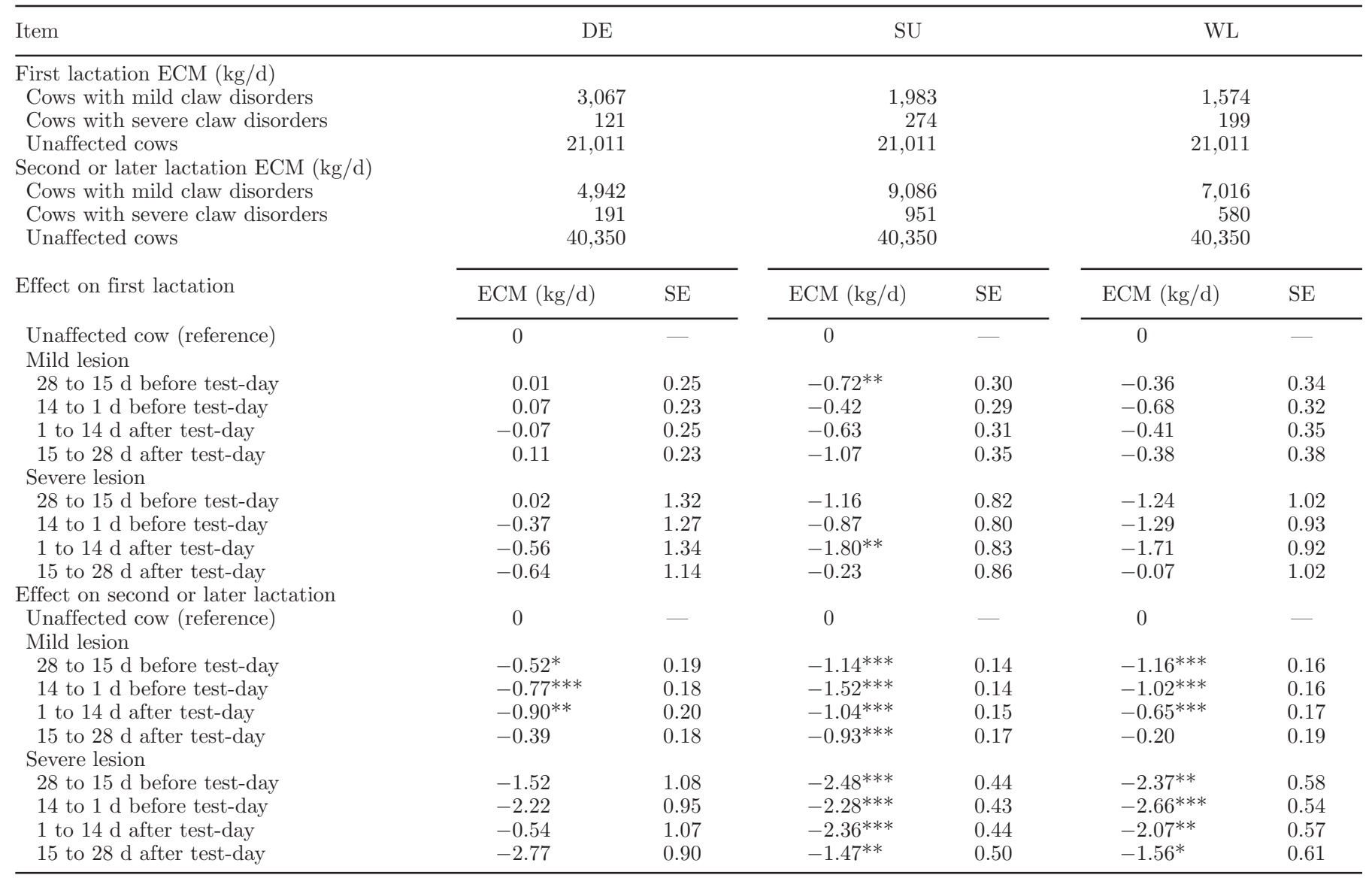

${ }^{1} \mathrm{DE}=$ dermatitis; $\mathrm{SU}=$ sole ulcer; $\mathrm{WL}=$ white line disease.

${ }^{*} P<0.05 ;{ }^{* *} P<0.01 ;{ }^{* *} P<0.001$ : statistical difference within a column with unaffected cow as reference. 
Table 6. Estimated effect of the severity of claw disorders ${ }^{1}$ diagnosed within the first $100 \mathrm{~d}$ of lactation on fertility performance compared with a cow without any claw disorder (unaffected cow) and their corresponding SE

\begin{tabular}{|c|c|c|c|c|c|c|}
\hline Item & \multicolumn{2}{|c|}{$\mathrm{DE}$} & \multicolumn{2}{|c|}{ SU } & \multicolumn{2}{|c|}{ WL } \\
\hline Cows with severe claw disorders & \multirow{2}{*}{\multicolumn{2}{|c|}{$\begin{array}{r}19 \\
12,129\end{array}$}} & \multirow{2}{*}{\multicolumn{2}{|c|}{$\begin{array}{r}70 \\
12,129\end{array}$}} & \multirow{2}{*}{\multicolumn{2}{|c|}{$\begin{array}{r}53 \\
12,129\end{array}$}} \\
\hline Unaffected cows & & & & & & \\
\hline Calving to first service interval (d) & Mean & SE & Mean & $\mathrm{SE}$ & Mean & $\mathrm{SE}$ \\
\hline Unaffected cow & 0 & - & 0 & - & 0 & - \\
\hline \multicolumn{7}{|l|}{ Days open $(\mathrm{d})$} \\
\hline Unaffected cow & 0 & - & 0 & - & 0 & - \\
\hline Mild lesion & -0.75 & 2.23 & $1.63^{* * *}$ & 2.40 & $3.03^{* *}$ & 2.40 \\
\hline Severe lesion & 5.40 & 17.41 & $17.37^{* *}$ & 8.13 & $8.59^{* *}$ & 9.59 \\
\hline \multicolumn{7}{|l|}{ Services per conception (no.) } \\
\hline Unaffected cow & 0 & - & 0 & - & 0 & - \\
\hline Mild lesion & -0.047 & 0.02 & $-0.058^{*}$ & 0.03 & $-0.032^{*}$ & 0.03 \\
\hline
\end{tabular}

${ }^{1} \mathrm{DE}=$ dermatitis; $\mathrm{SU}=$ sole ulcer; $\mathrm{WL}=$ white line disease.

${ }^{*} P<0.05 ;{ }^{* *} P<0.01 ;{ }^{* * *} P<0.001$ : statistical differences within a column with unaffected cow as reference.

\section{Effect of Claw Disorders on Longevity}

The longevity of a cow is determined by many factors in which a breeder's decision is crucial. As is common in the Spanish dairy cattle, breeders consider production level as very important and reproductive and health status are secondary. When a farmer makes a culling decision at an early parity, it suggests an involuntary culling related to reproductive and claw disorders. Due to this requirement, mean LPL in this study was 532 d (Table 1), far below the average LPL given by Chirinos et al. (2007) for the Spanish Holstein population (828-1,059 d depending on the region). Table 7 shows the effect of claw disorders on LPL. The occurrence of an event of SU and WL in first lactation had a significant effect on LPL, with a severe lesion reducing LPL from 59 to $71 \mathrm{~d}$. Other authors found that cows with claw disorders were culled $31 \mathrm{~d}$ before unaffected cows (Cramer et al., 2009) and that the hazard ratio of culling was 4.2 for cows in first lactation with lameness (Sogstad et al., 2007) and 2.7 for cows with SU in the first 4 mo of lactation (Booth et al., 2004). The effect of DE was not statistically significant for either a mild or a severe lesion. Cramer et al. (2009) found that infectious disorders were not associated with culling but white line lesions, ulcers, and hemorrhage were significantly associated with high hazard ratios. In our study, severe DE lesions had a strong effect on LPL, even though they were not statistically significant due to the small number of cows with severe DE in the final data set.

\section{Costs Due to Claw Disorders}

The costs estimated for each degree of severity of each claw disorder, expressed per affected cow per year on the average farm under study, are shown in Table 8. The costs of severe lesions were almost 3 times higher

Table 7. Estimated effect of the severity of claw disorders ${ }^{1}$ diagnosed within first lactation on length of productive life (LPL) compared with a cow without any claw disorder (unaffected cow) and their corresponding standard SE

\begin{tabular}{|c|c|c|c|c|c|c|}
\hline Item & \multicolumn{2}{|c|}{$\mathrm{DE}$} & \multicolumn{2}{|c|}{$\mathrm{SU}$} & \multicolumn{2}{|c|}{ WL } \\
\hline LPL (d) & Mean & $\mathrm{SE}$ & Mean & $\mathrm{SE}$ & Mean & $\mathrm{SE}$ \\
\hline $\begin{array}{l}\text { Unaffected cow } \\
\text { Mild lesion } \\
\text { Severe lesion }\end{array}$ & $\begin{array}{c}0 \\
-2.06 \\
-61.31\end{array}$ & $\begin{array}{r}- \\
8.11 \\
38.96\end{array}$ & $\begin{array}{c}0 \\
-38.03^{* *} \\
-59.11^{*}\end{array}$ & $\begin{array}{l}-\overline{11.84} \\
29.01\end{array}$ & $\begin{array}{c}0 \\
-34.55^{* *} \\
-70.92^{*}\end{array}$ & $\begin{array}{l}\overline{12.19} \\
36.20\end{array}$ \\
\hline
\end{tabular}

${ }^{1} \mathrm{DE}=$ dermatitis; $\mathrm{SU}=$ sole ulcer; $\mathrm{WL}=$ white line disease.

${ }^{*} P<0.05 ;{ }^{* *} P<0.01$ : statistical differences within a column with unaffected cow as reference. 
than the costs of mild lesions for all disorders because of the effect of severe lesions on longevity. Regarding the origin of the disorder, costs due to DE were lower than those for noninfectious disorders, mainly because of lower costs of treatment, extra labor, discarded milk, and milk losses. Discarded milk was the second most important cost but only in severe lesions because the treatment protocols of mild lesions did not involve the use of antibiotics, and therefore, the associated costs of discarded milk were zero.

Premature culling was the most important contributor among total costs, except for mild DE, where trimmer fees represented the largest cost because mild DE had a lesser effect on performance and a shorter duration than SU and WL lesions. In general, indirect costs (reduction of milk production, worsening of fertility performance, and premature culling), which are often considered hidden costs because the farmer is not aware of their magnitude, were higher than direct costs, between 43 and $60 \%$ of the total costs, mainly because of premature culling and milk production losses. The cost of reduced reproductive efficiency ranged from 10 to $20 \%$ of the total costs, depending on the lesion and degree of severity. This contribution to total cost was lower than that estimated in previous studies (Willshire and Bell, 2009; Cha et al., 2010), where fertility costs represented between 30 and $45 \%$ of annual costs. However, Verhoef (2014) reported that fertility contributed over $10 \%$ of the total costs for a claw disorder clinical case, and Esslemont and Kossaibati (2002) estimated the cost of longer calving interval for an average lameness case to be $21 \%$ of total costs. In the current study, discarded milk accounted for almost half of the direct costs. For the average herd described in Table 2, taking into account the incidence of each claw disorder (Table 2 ) and the costs per affected cow (Table 8), annual costs per cow of DE, SU, and WL were $\$ 10.80, \$ 50.90$, and $\$ 43.20$, respectively. Therefore, for a herd with
64 cows, costs due to DE were $\$ 691 / \mathrm{yr}$, costs due to SU were $\$ 3,256 / \mathrm{yr}$, and costs due to WL were $\$ 2,765 /$ yr. The most frequent disorders were SU and WL, which are those with a greater effect on milk production, fertility, and productive life. Severe cases for all 3 disorders represented only $10 \%$ of the total number of cases, although their contribution to the economic loss per herd and per year was about 30\%. Prompt detection and early and effective treatment could decrease the incidence of severe cases and reduce the extent of economic losses.

It is difficult to compare our results with those of other authors because of the different parameters and economic values considered for each study. There is a general agreement in the results found in the literature regarding the greater economic impact of noninfectious disorders than infectious disorders. Using dynamic programming, Cha et al. (2010) reported that noninfectious disorders resulted in higher costs than infectious disorders, mainly because the main contributor to SU costs $(\$ 216.07 /$ case $)$ was milk loss, whereas treatment was the most relevant contributor to costs for digital dermatitis (\$132.96/case). Willshire and Bell (2009) estimated that SU and WL contributed to $81 \%$ of the costs by lesion for a herd, with the costs of a case of digital dermatitis being only $2 \%$. Bruijnis et al. (2010) reported that the average cost of a clinical claw disorder was $\$ 95$ and that of a subclinical disorder was $\$ 18$, with the highest costs due to digital dermatitis because it was the most prevalent disorder among those studied. We agree, however, with Bruijnis et al. (2010) on the importance of economic losses caused by milk losses and premature culling. The total costs due to DE estimated in our study were lower than those estimated by Bruijnis et al. (2010) in Dutch dairy cattle but the total costs we estimated for SU and WL were higher. This difference was mainly due to differences in the incidence of each disorder between both populations.

Table 8. Breakdown of annual estimated costs (\$/affected cow) with mild or severe lesions of each claw disorder

\begin{tabular}{|c|c|c|c|c|c|c|}
\hline \multirow[b]{2}{*}{ Cost } & \multicolumn{2}{|c|}{$\mathrm{DE}$} & \multicolumn{2}{|c|}{$\mathrm{SU}$} & \multicolumn{2}{|c|}{ WL } \\
\hline & Mild & Severe & Mild & Severe & Mild & Severe \\
\hline \multicolumn{7}{|l|}{ Direct } \\
\hline Treatment & 3.7 & 16.9 & 33.8 & 72.5 & 36.2 & 68.3 \\
\hline Trimmer & 22.5 & 33.8 & 25.3 & 77.1 & 27.2 & 51.2 \\
\hline Extra labor & 3.7 & 25.3 & 33.8 & 65.3 & 36.2 & 61.5 \\
\hline Discarded milk & - & 98.1 & - & 125.7 & - & 118.4 \\
\hline \multicolumn{7}{|l|}{ Indirect } \\
\hline Milk yield reduction & 17.9 & 66.0 & 42.4 & 98.6 & 29.6 & 97.9 \\
\hline Additional days open & 0.0 & 11.8 & 3.6 & 37.9 & 6.6 & 18.7 \\
\hline Premature culling & 5.1 & 150.6 & 93.4 & 145.1 & 84.9 & 174.1 \\
\hline Total & 53.0 & 402.4 & 232.3 & 622.3 & 220.6 & 590.3 \\
\hline
\end{tabular}

${ }^{1} \mathrm{DE}=$ dermatitis; $\mathrm{SU}=$ sole ulcer; $\mathrm{WL}=$ white line disease. 


\section{CONCLUSIONS}

This study demonstrated that claw disorders have an important effect on production and performance of cows. Cases of DE, SU, and WL reduced milk production, led to longer days open intervals, and decreased productive life. These disorders led to a yearly loss of over $\$ 6,700$ per average Spanish herd of approximately 64 cows, even though we considered only cows having one disorder at time. If we consider that cows could have more than one disorder at time, the economic losses would be higher. Severe lesions were less frequent by far but typically led to economic losses 3 times greater than those associated with mild lesions. Moreover, more than half of the costs were not obvious to the farmer (e.g., indirect costs due to milk losses, worsening of fertility, and premature culling). If the farmer were aware of the magnitude of those costs in the herd, they might make better decisions on how to improve herd management (e.g., implementing preventive trimming) to reduce the incidence of claw disorders. Data on lesion incidence and economic costs could be used to develop farm-based decision support tools that could assist farmers tackle lameness issues on their farms in the most cost-effective manner.

\section{ACKNOWLEDGMENTS}

The authors thank the Spanish Holstein Association (CONAFE, Valdemoro, Spain) for their financial support (grant agreement 4155680 UCM-CONAFE), as well as Seragro Sociedad Coperativa Gallega (A Coruña, Spain), Anka Hoof Care (Navarra, Spain), and all the trimmers, for their vital role in this study.

\section{REFERENCES}

Amory, J. R., Z. E. Barker, J. L. Wright, S. A. Mason, R. W. Blowey, and L. E. Green. 2008. Associations between sole ulcer, white line disease and digital dermatitis and the milk yield of 1824 dairy cows on 30 dairy cow farms in England and Wales from February 2003-November 2004. Prev. Vet. Med. 83:381-391.

Barkema, H. W., J. D. Westrik, K. A. S. van Keulen,, Y. H. Schukken, and A. Brand. 1994. The effects of lameness on reproductive performance, milk production and culling in Dutch dairy farms. Prev. Vet. Med. 20:249-259.

Bell, N. J., M. J. Bell, T. G. Knowles, H. R. Whay, D. J. Main, and A. J. F. Webster. 2009. The development, implementation and testing of a lameness control programme based on HACCP principles and designed for heifers on dairy farms. Vet. J. 180:178-188.

Bicalho, R. C., V. S. Machado, and L. S. Caixeta. 2009. Lameness in dairy cattle: A debilitating disease or a disease of debilitated cattle? A cross-sectional study of lameness prevalence and thickness of the digital cushion. J. Dairy Sci. 92:3175-3184.

Bicalho, R. C., F. Vokey, H. N. Erb, and C. L. Guard. 2007. Visual locomotion scoring in the first seventy days in milk: Impact on pregnancy and survival. J. Dairy Sci. 90:4586-4591.

Booth, C. J., L. D. Warnick, Y. T. Grohn, D. O. Maizon, C. L. Guard, and D. Janssen. 2004. Effect of lameness on culling in dairy cows. J. Dairy Sci. 87:4115-4122.
Bruijnis, M. R. N., H. Hogeveen, and E. N. Stassen. 2010. Assessing economic consequences of foot disorders in dairy cattle using a dynamic stochastic simulation model. J. Dairy Sci. 93:2419-2432.

Buch, L. H., A. C. Sorensen, J. Lassen, P. Berg, J. A. Erikson, J. H. Jakobsen, and M. K. Sorensen. 2011. Hygiene-related and feedrelated hoof diseases show different patterns of genetic correlations to clinical mastitis and female fertility. J. Dairy Sci. 94:1540-1551.

Cha, E., J. A. Hertl, D. Bar, and Y. T. Gröhn. 2010. The cost of different types of lameness in dairy cows calculated by dynamic programming. Prev. Vet. Med. 97:1-8.

Charfeddine, N., and M. A. Pérez-Cabal. 2014a. Claw health data recording in Spanish dairy cattle. ICAR, Berlin, Germany. Accessed Dec. 28, 2015. http://www.icar.org/wp-content/uploads/2015/09/ Charfeddine.pdf.

Charfeddine, N., and M. A. Pérez-Cabal. 2014b. Pesos económicos para actualizar el ICO. Frisona Española, 204:36-39. Accessed Mar. 9, 2016. http://www.revistafrisona.com/Portals/0/articulos/ n204/Pesos\%20econ\%C3\%B3micos\%20ICO.pdf.

Chirinos, Z., M. J. Carabaño, and D. Hernandez. 2007. Genetic evaluation of length of productive life in the Spanish Holstein-Friesian population. Model validation and genetic parameters estimation. Livest. Prod. Sci. 106:120-131.

Clarkson, M. J., D. Y. Downham, W. B. Faull, J. W. Hughes, F. J. Manson, J. B. Merritt, R. D. Murray, W. B. Russell, J. E. Sutherst, and W. R. Ward. 1996. Incidence and prevalence of lameness in dairy cattle. Vet. Rec. 138:563-567.

Collick, D. W., W. R. Ward, and H. Dobson. 1989. Associations between types of lameness and fertility. Vet. Rec. 125:103-106.

Cook, N. B. 2003. Prevalence of lameness among dairy cattle in Wisconsin as a function of housing type and stall surface. J. Am. Vet. Med. Assoc. 223:1324-1328.

Cramer, G., K. D. Lissemore, C. L. Guard, K. E. Leslie, and D. F. Kelton. 2008. Herd- and cow-level prevalence of foot lesions in Ontario dairy cattle. J. Dairy Sci. 91:3888-3895.

Cramer, G., K. D. Lissemore, C. L. Guard, K. E. Leslie, and D. F. Kelton. 2009. The association between foot lesions and culling risk in Ontario Holstein cows. J. Dairy Sci. 92:2572-2579.

de Vries, M., and R. Veerkamp. 2000. Energy balance of dairy cattle in relation to milk production variables and fertility. J. Dairy Sci. 83:62-69.

Dobson, H., and R. F. Smith. 2000. What is stress and how does it affect reproduction? Anim. Reprod. Sci. 60-61:743-762.

Döpfer, D., A. Koopmans, F. A. Meijer, I. Szakáll, Y. H. Schukken, W. Klee, R. B. Bosma, J. L. Cornelisse, A. J. A. M. van Asten, and A. A. H. M. ter Huurne. 1997. Histological and bacteriological evaluation of digital dermatitis in cattle, with special reference to spirochaetes and Campylobacter faecalis. Vet. Rec. 140:620-623.

Esslemont, R. J., and M. A. Kossaibati. 2002. DAISY Research Report No. 5: The costs of poor fertility and disease in UK dairy herdsTrends in DAISY herds over 10 seasons. Intervet UK Ltd., Milton Keynes, United Kingdom.

Fourichon, C., H. Seegers, and X. Malher. 2000. Effect of disease on reproduction in the dairy cow: A meta-analysis. Theriogenology $53: 1729-1759$

Garbarino, E. J., J. A. Hernandez, J. K. Hearer, C. A. Risco, and W. W. Thatcher. 2004. Effect of lameness on ovarian activity in postpartum Holstein cows. J. Dairy Sci. 87:4123-4131.

Green, L. E., J. Borkert, G. Monti, and N. Tadich. 2010. Associations between lesion-specific lameness and the milk yield of 1635 dairy cows from seven herds in the Xth region of Chile and implications for the management of dairy cows worldwide. Anim. Welf. 19:419-427.

Green, L. E., V. J. Hedges, Y. H. Schukken, R. W. Blowey, and A. J. Packington. 2002. The impact of clinical lameness on the milk yield of dairy cows. J. Dairy Sci. 85:2250-2256.

Green, L. E., J. N. Huxley, C. Banks, and M. J. Green. 2014. Temporal associations between low body condition, lameness and milk yield in a UK dairy herd. Prev. Vet. Med. 113:63-71.

Hernandez, J., J. K. Shearer, and D. W. Webb. 2001. Effect of lameness on the calving-to- conception interval in dairy cows. J. Am. Vet. Med. Assoc. 218:1611-1614. 
Hernandez, J., J. K. Shearer, and D. W. Webb. 2002. Effect of lameness on milk yield in dairy cows. J. Am. Vet. Med. Assoc. 220:640-644.

Hernandez, J. A. 2005. Comparison of milk yield in dairy cows with different degrees of lameness. J. Am. Vet. Med. Assoc. 227:12921296.

Hultgren, J., T. Manske, and C. Bergsten. 2004. Associations of sole ulcer at claw trimming with reproductive performance, udder health, milk yield, and culling in Swedish dairy cattle. Prev. Vet. Med. 62:233-251.

Huxley, J. N. 2013. Impact of lameness and claw lesions in cows on health and production. Livest. Sci. 156:64-70.

IFCN. 2010. IFCN dairy report. IFCN, Kiel, Germany. Accessed Apr. 21, 2016. http://www.ifcndairy.org/en/methods/dairysector/ index.php.

Kossaibati, M. A., and R. J. Esslemont. 1997. The costs of production diseases in dairy herds in England. Vet. J. 154:41-51.

Leach, K. A., H. R. Whay, C. M. Maggs, Z. E. Barker, E. S. Paul, A. K. Bell, and D. C. J. Main. 2010. Working towards a reduction in cattle lameness: 1 . Understanding barriers to lameness control on dairy farms. Res. Vet. Sci. 89:311-317.

Lim, P. Y., J. N. Huxley, J. A. Willshire, M. J. Green, A. R. Othman, and J. Kaler. 2015. Unravelling the temporal association between lameness and body condition score in dairy cattle using a multistate modelling approach. Prev. Vet. Med. 118:370-377.

Lischer, C. J., and P. Ossent. 2000. Sole ulcers in dairy cattle - What's new about an old disease? Pages 46-48 in XI Int. Symp. Disorders of the Ruminant Digit, Parma, Italy.

Melendez, P., J. Bartolome, L. F. Archbald, and A. Donovan. 2003. The association between lameness, ovarian cysts and fertility in lactating dairy cows. Theriogenology 59:927-937.

Murray, R. D., D. Y. Downham, M. J. Clarkson, W. B. Faull, J. W. Hughes, F. J. Manson, J. B. Merritt, W. B. Russell, J. E. Sutherst, and W. R. Ward. 1996. Epidemiology of lameness in dairy cattle: description and analysis of foot lesions. Vet. Rec. 138:586-591.

Olechnowicz, J., and J. M. Jaśkowski. 2015. Associations between different degrees of lameness in early lactation and the fertility of dairy cows. Med. Weter. 71:36-40.

Oltenacu, P. A., and B. Algers. 2005. Selection for increased production and the welfare of dairy cows: are new breeding goals needed? Ambio 34:311-315.

Onyiro, O. M., L. J. Andrews, and S. Brotherstone. 2008. Genetic parameters for digital dermatitis and correlation with locomotion, production, fertility traits, and longevity in Holstein-Friesian dairy cows. J. Dairy Sci. 91:4037-4046.

Pérez-Cabal, M. A., and N. Charfeddine. 2015. Models for genetic evaluations of claw health traits in Spanish dairy cattle. J. Dairy Sci. 98:8186-8194.

Räber, M., M. R. Scheeder, P. Ossent, C. Lischer, and H. Geyer. 2006. The content and the composition of lipids in the digital cushion of the bovine claw with respect to age and location-A preliminary report. Vet. J. 172:173-177.

Rajala-Schultz, P. J., Y. T. Gröhn, and C. E. McCulloch. 1999. Effect of milk fever, ketosis, and lameness on milk yield in dairy cows. J. Dairy Sci. 82:288-294.

Relun, A., A. Lehebel, A. Chesnin, R. Guatteo, and N. Bareille. 2013. Association between digital dermatitis lesions and test-day milk yield of Holstein cows from 41 French dairy farms. J. Dairy Sci. 96:2190-2200.

Sogstad, Å. M., O. Østerås, T. Fjeldaas, and O. Nafstad. 2007. Bovine claw and limb disorders related to culling and carcass characteristics. Livest. Sci. 106:87-95.

Somers, J. G. C. J., K. Frankena, E. N. Noordhuizen-Stassen, and J. H. M. Metz. 2003. Prevalence of claw disorders in Dutch dairy cows exposed to several floor systems. J. Dairy Sci. 86:2082-2093.

Stoop, W. M., G. de Jong, M. L. van Pelt, and C. van der Linde. 2010. Implementation of a claw health index in The Netherlands. Interbull Bull. 42:95-99.

Uggla, E., J. H. Jakobsen, C. Bergsten, J.-A. Erisson, and E. Strandberg. 2008. Genetic correlation between claw health and feet and leg conformation traits in Swedish dairy cows. Interbull Bull. 38:91-95.

van der Waaij, E. H., M. Holzhauer, E. Ellen, C. Kamphuis, and G. De Jong. 2005. Genetic parameters for claw disorders in Dutch dairy cattle and correlations with conformation traits. J. Dairy Sci. 88:3672-3678.

Verhoef, G. G. M. 2014. Economic impact of foot disorders in dairy cattle. Dissertation. Universität Utrecht. Faculty of Veterinary Medicine Theses. Accessed July 21, 2016. http://dspace.library. uu.nl/handle/1874/289377.

Warnick, L. D., D. Jansen, C. L. Guard, and Y. T. Gröhn. 2001. The effect of lameness on milk production in dairy cows. J. Dairy Sci. 84:1988-1997.

Willshire, J. A., and N. J. Bell. 2009. An economic review of cattle lameness. Cattle Pract. 17:136-141. 